\title{
PENGGUNAAN UPAYA HUKUM NOVASI DALAM PENYELESAIAN PERMASALAHAN HUKUM PERUSAHAAN YANG MENGALAMI KERUGIAN
}

\section{Gede Angga Permana}

${ }^{1}$ Fakultas Hukum, Program Studi Magister Kenotariatan, Universitas Udayana, E-mail: osteon001st@yahoo.com

\begin{tabular}{l}
\hline Info Artikel \\
\hline Masuk: \\
Diterima : \\
Terbit : \\
Keywords : \\
Novation; Legal Issue; \\
Company;Loss \\
\\
\\
\\
Kata kunci: \\
Novasi;Permasalahan \\
Hukum;Perusahaan; Kerugian. \\
Corresponding Author: \\
I Gede Angga Permana,E-mail: \\
osteon001st@yahoo.com/osteon00 \\
1st@gmail.com \\
DOI : \\
Xxxxxx
\end{tabular}

\begin{abstract}
This research was conducted because of Indonesian people's unawareness on the legal effort of novation in solving legal issue of a company which experience loss and the differences between novation and suspension of debt payment obligation. Generally, this research aimed at providing knowledge and insight. Specifically, it aimed at discussing the concept of novation, the legal effort of novation in solving legal issue of a company which experiences loss, as well as discussing the differences between novation and suspension of debt payment obligation. Normative method was used in this research. The result of this study shows that there are several points that should be done in implementing the concept of novation. First, there should be an agreement of debt payment obligation in the first place. Second, the debtor should be proven of being unable to pay his debt, and further if there was a loss experienced, the debtor and creditor can conduct a legal effort of novation or debt renewal agreement.
\end{abstract}




\section{Pendahuluan}

Perkembangan perusahaan di Indonesia sangatlah pesat, dengan pesatnya perkembangan atau pertumbuhan usaha di Indonesia mengakibatkan meningkatnya pertumbuhan ekonomi di Indonesia. Perusahaan di Indonesia mempunyai tugas dan fungsional yang begitu dibutuhkan atau diperlukan di dalam kehidupan masyarakat Indonesia karena perusahaan dapat menampung banyak tenaga kerja, selain itu perusahaan juga merupakan penghasilan bagi negara melalui pemungutan pajak.

Definisi Perusahaan berdasarkan Undang-Undang Republik Indonesia Pasal 1 huruf b Nomor 3 Tahun 1982 Tentang Wajib Daftar Perusahaan yang mengatur sebagai berikut: "perusahaan adalah semua ciri-ciri kegiatan perdagangan yang melakukan semua macam-macam kegiatan perdagangan yang memiliki sifat konsisten serta tanpa terputus-putus, serta didirikan, operasional, serta harus memiliki domisili di daerah kedudukan bangsa Indonesia atau negara Indonesia, yang memiliki kepentingan untuk mencari penghasilan ekonomi”. Sedangkan menurut Rachmadi Usman perusahaan adalah badan usaha yang melakukan kegiatan operasional di bidang ekonomi yang dilakukan secara teratur dan konsisten serta memiliki tujuan untuk mendapatkan penghasilan ekonomi . ${ }^{1}$ Berdasarkan definisi perusahaan menurut Pasal 1 huruf b di atas, perusahaan memiliki macam-macam bagian-bagian pokok supaya bisa dinyatakan sebagai suatu perusahaan.

a. Semua bentuk-bentuk usaha yang melakukan semua jenis-jenis kegiatan usaha;

b. Memiliki sifat konsisten dan tidak terputus-putus;

c. Didirikan, operasional, serta memiliki domisili di wilayah Indonesia;

d. Bertujuan untuk mendapatkan penghasilan ekonomi.

Seiring berjalannya suatu perusahaan mengakibatkan perusahaan-perusahaan di Indonesia melakukan berbagai macam kontrak atau perjanjian utang-piutang yang sering disebut dengan istilah novasi. Pada umunnya masyarakat di Indonesia masih sangat awam dengan istilah novasi atau perjanjian pembaruan utang, karena memang perbuatan ini hanya sering dilakukan oleh perusahaan atau pelaku usaha di Indonesia. Walaupun memang peraturan-peraturan atau norma-norma hukum yang berkembang di Indonesia tidak mengatur pengertian atau definisi tentang novasi.

Novasi adalah suatu tahapan-tahapan penggantian kontrak yang sudah lampau dengan kontrak yang baru dibuat, sehingga mengakibatkan kontrak yang lampau tidak berlaku, maka yang sah secara hukum berlaku selanjutnya ialah kontrak yang baru dibuat, dengan pembaruan mengenai klausula-klausula yang memuat tantang syaratsyarat, keadaan, dan pembaruan mengenai pihak-pihak yang dimuat dalam kontrak. Dalam tahapan pembaruan utang, debitur dengan kreditur mencantumkan tanda tangan pada akta pembaruan utang. Akta yang dibuat tersebut akan menjadi pedoman atau acuan untuk melakukan tahapan-tahapan pembaruan utang. ${ }^{2}$

Novasi atau sering disebut juga sebagai pembaruan utang ada beberapa macam, ialah sebagai berikut:

1. Novasi objektif

${ }^{1}$ Abdul Rasyid Saliman, 2011, Hukum Bisnis Untuk Perusahaan: Teori Dan Contoh Kasus, Kencana, Jakarta, h. 91-92.

${ }^{2}$ Alfitri Satyaningrum, et.al , 2015, Problematikan Yuridis Pelaksanaan Novasi Subjektif Pasif Dalam Perjanjian Kredit Karena Pemberian Hak Tanggungan Meninggal Dunia, Jurnal Repertorium, ISSN:2355-2646, h. 21. 
Pembaruan utang ialah perbuatan hukum yang dilakukan debitur dengan menciptakan satu kontrak utang yang baru, yang memiliki fungsi untuk merubah utang yang lampau. Dalam peristiwa hukum ini yang dirubahnya kontrak yang lampau dengan kontrak yang baru bertujuan untuk membahas pokok persoalan mengenai utang-utangnya tanpa memperbaharui pihak kreditur atau pihak debitur;

2. Novasi subjektif aktif

Dilakukan penggantian kreditur lampau dengan kreditur baru, menimbulkan suatu akibat hukum antara debitur dengan kreditur lampau, sehingga kreditur lampau tidak memiliki hubungan hukum mengenai kontrak utang-piutang itu;

3. Novasi subjektif pasif

Perbuatan penggantian debitur lampau dengan debitur baru, dan kreditur menyepakati bahwa debitur lampau dilepaskan dari hak dan kewajibannya. ${ }^{3}$

Perusahaan-perusahaan di Indonesia membutuhkan modal untuk menjalankan usahanya, untuk mendapatkan modal perusahaan-perusahaan di Indonesia sering melakukan kontrak maupun perjanjian. Perusahaan-perusahaan yang melakukan kontrak atau perjanjian untuk mendapatkan modal dari kreditur sering kesusahan dalam mengembalikan modal yang diterima, sehingga tidak sedikit perusahaan-perusahaan yang mengalami kerugian dan tidak mampu membayar hutang-hutangnya kepada kreditur. Penyelesaian permasalahan perusahaan-perusahaan yang kesulitan mengembalikan hutang-hutangnya kepada kreditur biasanya menempuh upaya novasi atau penundaan kewajiban pembayaran utang (PKPU).

Kerugian menurut Kamus Besar Bahasa Indonesia ialah menanggung atau menderita rugi, menanggung atau menderita rugi ialah keadaan dimana seseorang dibebankan sesuatu yang tidak sesuai dengan nilainya. Kerugian sering terjadi di dalam dunia bisnis, kerugian akan terjadi jika sesuatu yang diinginkan tidak sesuai dengan nilai yang seharunya.

Masyarakat Negara Republik Indonesia belum sangat paham dengan hukum yang berkembang di wilayah Indonesia. sehingga masyarakat sering kesulitan membedakan novasi dengan penundaan kewajiban pembayaran utang (PKPU) dan kadang masyarakat sering menyamakan novasi dengan penundaan kewajiban pembayaran utang (PKPU). Sehingga perlu dilakukan suatu penulisan penelitian yang membahas mengenai perbendaan novasi dengan PKPU. Tulisan penelitian ini bertitik tolak dari desertasi yang berjudul "Penyelesaian Sengketa Utang Piutang Dengan Perdamaian Di Dalam Atau Di Luar Proses Kepailitan (Studi Mengenai Lembaga Penundaan Kewajiban Pembayaran Utang"4 sedangkan di dalam penulisan penelitian ini lebih memfokuskan penelitian terhadap upaya hukum non litigasi yaitu melalui novasi serta perbedaan novasi dengan PKPU.

Perbuatan menunda untuk melakukan pelunasan utang di atur dalam peraturan Undang-Undang Republik Indonesia Nomor 37 Tahun 2004 Tentang Kepailitan Dan Penundaan Kewajiban Pembayaran Utang, tidak diberikan definisi tentang perbuatan menunda untuk melakukan pelunasan utang. Penundaan kewajiban pembayaran utang (PKPU) ialah negosiasi tahapan-tahapan untuk mendamaikan yang diterapkan bagi debitur, suatu tindakan menyerahkan waktu keleluasaan terhadap debitur bagi

${ }^{3}$ Ibid.

${ }^{4}$ Manahan M. P. Sitompul, 2009, Penyelesaian Sengketa Utang Piutang Dengan Perdamaian Di Dalam Atau Di Luar Proses Kepailitan (Studi Mengenai Lembaga Penundaan Kewajiban Pembayaran Utang, Desertasi Program Pasca Sarjasa Universitas Sumatera Utara, Medan, h.1. 
menjalankan pengelolaan kembali utang-utangnya, yang bias mencakup pengembalian semua maupun setengah utangnya kepada kreditur. PKPU menyebabkan timbulnya suatu akibat hukum terhadap semua yang berkaitan dengan harta kekayaan debitur, semasa proses PKPU dilaksanakan, debitur tidak boleh diintimidasi, diancam, serta ditekan bagi melunasi utang yang dimilikinya, serta seluruh perbuatan pelaksanaan putusan yang berlangsung bagi mendapatkan pembayaran utang harus di tunda. ${ }^{5}$ PKPU atau Perbuatan menunda untuk melakukan pelunasan utang ini ialah perbuatan hukum yang akan dilaksanakan jika suatu perusahaan mengalami kepailitan atau mengalami kerugian dan tidak dapat membayar utang-utangnya kepada para kreditur.

\subsection{Tujuan Penelitian}

Penulisan penelitian dijalankan bagi tercapainya cita-cita serta tujuan yang diharapkan. Tujuan penelitian di dalam jurnal ini ada dua yaitu, pertama, tujuan secara umum berdasarkan penulisan penelitian ini, ialah sebagai berikut, memberi tambahan ilmu pengetahuan serta memberikan sumbangan kepada ilmu hukum perdata yang berkaitan dengan novasi atau persetujuan pembaruan utang. Sedangkan kedua, tujuan secara khusus mengenai penulisan penelitian ini yaitu, memahami serta mengenal konsep novasi atau perjanjian pembaruan utang di Indonesia, serta untuk mengetahui penyelesai masalah hukum perusahaan yang mengalami kerugian dengan menggunakan upaya hukum novasi novasi, dan untuk mengetahui perbedaan novasi dengan PKPU atau perbuatan menunda untuk melakukan pelunasan utang untuk mengatasi permasalah normatif mengenai perusahaan yang mengalami kerugian.

\section{Metode Penelitian}

\subsection{Jenis Penelitian}

Penulisan penelitian ini menggunakan jenis penelitian hukum normatif yang diterapkan di dalam penulisan penelitian ini, penulisan hukum secara normatif ialah penelitian yang diterapkan dengan mengkaji suatu peristiwa hukum atau fakta-fakta hukum berdasarkan norma-norma hukum yang ada. ${ }^{6}$ Penulisan penelitian ini diterapkan dengan menelaah bahan hukum primer, bahan hukum sekunder, dan bahan hukum tersier, bahan hukum yang disebutkan itu ialah berupa peraturan perundang-undangan, literature atau buku-buku, dan kamus-kamus. ${ }^{7}$ berikut:

Pendekatan yang digunakan di dalam penulisan penelitian ini ialah sebagai

1. Pendekatan analisis konsep hukum (analytical and conceptual approach)

\footnotetext{
${ }^{5}$ Kheriah, Independensi Pengurus Penundaan Kewajiban Pembayaran Utang (PKPU) Dalam Hukum Kepailitan, Jurnal Ilmu Hukum Riau, Volume 3 No.2, h. 240.

${ }^{6}$ I Gusti Agung Ayu Gita Priayanti Dinar, 2015, Penyelesaian Sengketa Pengalihan Saham Perusahaan Pembangkit Listrik Energy Panas Bumi Melalui Putusan Arbitrase Asing (SIAC), Jurnal Magister Hukum Udayana, Volume 4 No. 1: 48-56, h. 50.

7 I Wayan Sukatra, 2017, Kedudukan Dan Hak Bank Terhadap Hak Preferen Upah Buruh Dalam Kepailitan, Jurnal Magister Hukum Udayana, Volume 6 No. 3: 300- 309, h. 303.
} 
Pendekatan yang dilakukan menelaah segala permasalahan menurut asas-asas, teori, konsep dan norma hukum atau peraturan-peraturan hukum yang belaku di Indonesia. $^{8}$

2. Pendekatan peraturan perundang-undangan (the statue approach)

Pendekatan yang dilakukan dengan mengkaji, melakukan komparasi serta menganalisis asas, norma, konsep, serta prinisp yang termuat di dalam peraturan-peraturan hukum yang mengatur mengenai permasalahan yang akan dibahas. ${ }^{9}$

\subsection{Sumber Bahan Hukum}

Sumber bahan hukum yang diterapkan dalam penulisan penelitian ini yaitu:

1. Bahan hukum primer, ialah bahan yang memiliki kekuatan hukum memaksa dan merekat masyarakat yaitu, berbentuk peraturan-peraturan hukum yang dihunakan di Negara Indonesia.

2. Bahan hukum sekunder, yaitu bahan yang menyatakan pandangan dan penjabaran tentang bahan hukum primer, seperti literature, buku, atau penelitian-penelitian yang memiliki keterkaitan mengenai persoalan yang akan dibahas.

3. Bahan hukum tersier, yaitu bahan yang menyatakan suatu tanda atau isyarat yang memberitahu pendangan mengenai bahan hukum primer atau bahan hukum sekunder yang berbentuk kamus-kamus yuridis atau karya ilmiah yuridis. ${ }^{10}$

Untuk mencari atau untuk mendapatkan bahan yuridis yang diperlukan, maka harus dilakukan upaya dan tata-cara untuk mendapatkan bahan yuridis yang dibutuhkan. Tata-cara serta upaya pengumpulan bahan yuridis ini disebut dengan teknik pengumpulan bahan hukum. Tata-cara ini diterapkan menggunakan konsep pendekatan melalui memperlajari berkas-berkas yang memiliki keterkaitan dengan persoalan yang dikaji, hal ini disebut dengan istilah studi dokumen. Studi dokumen ialah tata-cara yang dilakukan untuk menelaah, meneliti serta menganalisis bahan-bahan yuridis yang telah terkumpul dan berkaitan mengenai permasalahan yang akan diteliti. ${ }^{11}$

Metoda analisis bahan hukum yang diterapkan di dalam penulisan penelitian ini, ialah dilakukan analisa berdasarkan jumlah atau banyaknya melalui tata-cara, ialah sebagai berikut:

a. Bahan yuridis yang telah didapatkan melalui teknik pengumpulan bahan hukum selanjutnya dilakukan penyusunan secara sistematis sesuai dengan urutan persoalan hukum yang akan dianalisis di dalam penulisan penelitian;

b. Setelah bahan yuridis tersusun secara sistematis, maka selanjutnya dilakukan perbandingan mengenai bahan-bahan yang didapatkan yang memiliki keterkaitan mengenai inti persoalan yang akan dibahas;

c. Bahan hukum yang telah dibandingkan lalu kemudia dilakukan evaluasi, serta diberikan argumentasi, di analisis, dan dikaji untuk diterapkan sebagai dasar

\footnotetext{
${ }^{8}$ Peter Mahmud Marzuki, 2011, Penelitian Hukum, Kencana, Jakarta, h. 137

${ }^{9}$ I gusti ayu gita pritayanti dinar, loc.cit.

${ }^{10}$ Natalia Ningsih, at.al, 2017, Kekuatan Mengikat Akta Notarial Perjanjian Perkawinan Terkait Harta Bersama Yang Dibuat Pasca Pencatatan Perkawinan, Acta Comitas, Volume 2 No. 1, h. 16.

${ }^{11}$ Bagus Gede Ardiartha Prabawa, 2017, Analisis Yuridis Tentang Hak Ingkar Notaris Dalam Hal Pemeriksaan Menurut Undang-Undang Jabatan Notaris Dan Kode Etik Notaris, Acta Comitas, Volume 2 No. 1, h. 104.
} 
mengambil kesimpulan mengenai permasalahan yang di bahas di dalam penelitian. $^{12}$

\section{Hasil dan Pembahasan}

\subsection{Upaya Hukum Novasi (Perjanjian Pembaruan Utang)}

\subsubsection{Konsep Novasi (Perjanjian Pembaruan Utang)}

Pengertian novasi dalam peraturan-peraturan hukum tidak diberikan pengertian yang cukup jelas, namun dalam peraturan hukum perdata atau KUHPer, novasi diartikan manjadi pembaruan utang. Pembaruan utang yang dimaksud dilakukan dalam bentuk kontrak atau perjanjian yang dilakukan secara tertulis. Sedangkan di dalam Kamus Besar Bahasa Indonesia novasi ialah penggantian partai kontrak, penggantian utang atau tanggungan sebelumnnya oleh utang atau tanggungan yang baru. Pembaruan utang atau novasi ini merupakan suatu kontrak atau perjanjian yang tertulis yang dibuat atas dua subjek hukum atau beberapa subjek hukum yang dapat melengkapi tuntutan atau permintaan yang tertuang dalam hukum suatu persetujuan. Novasi atau pembaruan utang sering dilakukan oleh masyarakat di Indonesia untuk memnuhi kebutuhan modal dan kepentingan para pihak yang membuat pembaruan utang tersebut. Persetujuan pembaruan utang ini sering dilakukan oleh para pelaku usaha untuk mendapatkan modal menjalankan usahanya atau untuk mendirikan perusahaan baru.

Novasi di Indonesia belum diberikan definisi oleh peraturan perundangundangan namun novasi di dalam hukum perdata dikenal juga sebagai persetujuan pembaruan utang yang di atur di dalam peraturan hukum perdata atau KUHPer Pasal 1413- Pasal 1424. Novasi merupakan salah satu jenis perjanjian yang di kenal di dalam KUHPer yang disebut dengan istilah perjanjian utang-piutang.

Berdasarkan Pasal 1413-1424 dapat dilihat konsep novasi, yang mana novasi merupakan suatu persetujuan pembaruan utang yang dilakukan oleh debitur dengan kreditur yang dibuat dalam bentuk akta. Pembaruan utang ini dilakukan setelah adanya perjanjian atau persetujuan utang-piutang, novasi atau pembaruan utang ini dilakukan jika debitur tidak mampu membayar utang-utangnya kepada kreditur.

Berdasarkan konsep mengenai novasi diatas dapat dikatakan bahwa untuk dapat dikatan sebagai novasi harus memenuhi beberapa unsur yaitu:

a. Merupakan suatu persetujuan pembaruan utang;

Pada dasarnya novasi merupakan kesepakatan yang dilakukan oleh dua orang atau lebih, yang sepakat atas suatu hal tertentu.

b. Dibuat dalam bentuk akta Notaris;

Novasi atau persetujuan pembaruan utang ini harus dilakukan berupa tulisan yang dimuatkan dalam suatu akta, sesuai dengan peraturan Pasal 1415 peraturan hukum perdata atau KUHPer, yang menentukan yaitu "kesepakatan membuat pembaharuan utang tidak boleh diperkirakan; maksud dan tujuan seseorang untuk menyepakati persetujuan itu harus termuat dan terbukti di dalam isi akta"

c. Dilakukan setelah ada perjanjian atau persetujuan utang-piutang;

\footnotetext{
${ }^{12}$ Ibid, h. 104-105.
} 
Sebelum dilakukan perjanjian pembaruan utang atau novasi, maka terlebih dahulu harus diawali dengan adanya perjanjian utang-piutang, jika belum ada perjanjian utang-piutang tidak dapat dilakukan novasi atau perjanjian pembaruan utang.

d. Dilakukan jika debitur tidak mampu membayar utang-utangnya;

Novasi atau perjanjian pembaruan utang baru dapat dilakukan jika debitur memang secara nyata tidak dapat membayar utang-utangnya, novasi atau perjanjian pembaruan utang tidak dapat dilakukan jika secara nyata debitur masih mampu melakukan pembayaran utang-utangnya.

Mengingat bahwa novasi merupakan suatu jenis perjanjian atau kesepakatan yang ada, maka novasi harus sesuai dengan asas perjanjian atau kesepakatan yang diatur di dalam peraturan hukum perdata atau KUHPer Pasal 1313, yang menentukan, ialah "perjanjian merupakan sesuatu tindakan hukum yang dilaksanakan atas dua subjek hukum atau beberapa subjek hukum, secara bersama-sama menyepakati kepada dua subjek hukum lainnya atau beberapa subjek hukum". Atas pemaparan yang telah disebutkan itu bisa dikatakan bahwa perjanjian ialah adanya dua subjek hukum atau lebih yang mengikatkan dirinya untuk berbuat sesuatu yang diperjanjikan dan pihakpihak tersebut menyepakati hal tersebut. ${ }^{13}$ Perjanjian merupakan ketentuan yang memuat bahwa tiap-tiap orang memiliki hak serta kewajibannya sesuai dengan ketentuan yang diatur atau dimuat di dalam perjanjian. ${ }^{14}$

Novasi sebagai suatu perjanjian pembaruan utang baru diakui perjanjian atau kesepakatan setelah terpenuhinya unsur-unsur perjanjian atau kesepakatan di dalam ketentuan Pasal 1320 peraturan hukum perdata atau KUHPer yang menentukan suatu persetujuan atau perjanjian baru dikatakan sah, bila dipenuhi empat syarat ialah;

1. Adanya konsensus para subjek hukum yang akan melakukan persetujuan.

Dalam hal ini artinya ada subjek hukum minimal dua subjek hukum atau beberapa subjek hukum yang melakukan suatu kesepakatan;

2. Cakap dalam melakukan persetujuan

Kecakapan dalam hal ini artinya orang yang melakukan perbuatan harus sudah dewasa menurut peraturan hukum perdata atau KUHPer;

3. Beberapa pokok persoalan

Pokok persoalan tertentu ini artinya ialah adanya objek yang diperjanjikan atau dipersetujukan oleh para pihak, bisa dalam bentuk barang yang dapat berpindah serta barang yang tidak dapat dipindahkan, baik itu berupa ataupun tidak memiliki rupa, yang bentuk objek diperjanjikan itu memiliki nilai bagi para pihak;

4. Beberapa faktor yang tidak diperbolehkan

Bagian persoalan ini artinya apa yang disepakati atau yang sipersetujukan tidak melanggar norma-norma atau peraturang perundang-undangan yang ada di Indonesia.

13 Anak Agung Adi Lestari, 2016, Perjanjian Baku Dalam Jual Beli Kredit Sepeda Motor Ditinjau Dari Undang-Undang Nomor 8 Tahun 1999, Jurnal Magister Hukum Udayana, Volume 5 No.2: 337-352, h. 338

${ }^{14}$ I Gusti Bagas Arya Anggara Paramarta, 2017, Akibat Hukum Perjanjian Lisensi Terhadap Pihak Ketiga, Acta Comitas, Volume 2 No.1, h. 77. 
Berdasarkan pemaparan diatas, untuk dapat dikatan sebagai novasi atau perjanjian pembaruan utang maka harus memenuhi unsur-unsur perjanjian atau persetujuan di dalam Pasal 1320 Peraturan hukum perdata atau KUHPer dan juga harus memenuhi unsur-unsur novasi di dalam Pasal 1413-1424 KUHPer. Untuk dapat dikatakan novasi memang harus memenuhi unsur perjanjian dan unsur novasi karena memang novasi ini merupakan suatu perjanjian maka pertama harus terpenuhi unsur perjanjian dan kedua harus terpenuhi unsur novasinya.

\subsubsection{Penyelesaian Permasalahan Perusahaan yang Mengalami Kerugian dengan Menggunakan Upaya Hukum Novasi}

Berkembangnya Indonesia pada masa global seperti saat ini mengakibatkan persaingan ekonomi semakin ketat. Dengan ketatnya persaingan ekonomi di Indonesia mengakibatkan pelaku usaha atau masyarakat Indonesia melakukan kegiatan usaha dengan membuat atau mendirikan perusahaan. Perusahaan ini memiliki banyak jenis kegiatan usaha yang dapat dilakukan baik itu dalam perindustrian, pariwisata, peternakan dan sebagainya.

Mengingat bahwa persaingan ekonomi di Indonesia semakit ketat, maka pelaku usaha mendirikan atau membuat perusahaan yang memiliki tujuan untuk mendapatkan penghasilan ekonomi, yang mana penghasilan ekonomi ini dapat meningkatkan finansial dari pelaku usaha atau masyarakat Indonesia baik itu pemiliki usaha maupun orang yang bekerja di dalam perusahaan tersebut. Perusahaan juga memiliki fungsi dan peran yang sangat penting bagi negara, karena perusahaan dapat menciptakan lapangan pekerjaan yang luas dan memberikan penghasilan kepada negara melalui pajak.

Perusahaan di dalam Kamus Besar Bahasa Indonesia (KBBI) diartikan sebagai organisasi berbadan hukum yang mengadakan transaksi atau kegiatan usaha (pekerjaan dan sebagainya) yang diselenggarakan dengan peralatan atau dengan cara teratur dengan tujuan mencari keuntungan (dengan menghasilkan sesuatu, mengolah atau membuat barang-barang, berdagang, memberikan jasa, dan sebagainya). Sedangkan pengertian perusahaan menurut Molengraaf, perusahaan adalah keseluruhan perbuatan yang dilakukan secara terus-menerus, bertindak keluar, untuk mendapat penghasilan, dengan cara memperniagakan barang-barang atau mengadakan perjanjian-perjanjian perdangan. ${ }^{15}$ Selain pengertian perusahaan menurut KBBI dan menurut doktrin dalam peraturan hukum Indonesia juga dimuat mengenai definisi perusahaan.

Perusahaan berdasarkan peraturan Undang-Undang Republik Indonesia Pasal 1 huruf b Nomor 3 Tahun 1982 Tentang Wajib Daftar Perusahaan yang mengatur ialah sebagai berikut: "perusahaan adalah semua ciri-ciri kegiatan perdagangan yang melakukan semua macam-macam kegiatan perdagangan yang memiliki sifat konsisten serta tanpa terputus-putus, serta didirikan, operasional, serta harus memiliki domisili di daerah kedudukan bangsa Indonesia atau negara Indonesia, yang memiliki kepentingan untuk mencari penghasilan ekonomi”.

Pelaku usaha atau masyarakat yang ingin mendirikan suatu perusahaan yang ingin menjalankan beberapa jenis usaha biasanya membutuhkan modal untuk mendirikan perusahaan sebagai modal dasar perusahaan. Modal ini biasanya didapat melalui uang yang dimiliki pihak-pihak yang ingin mendirikan perusahaan atau modal yang didapat dengan meminjam kepada para kreditur yang biasanya dilakukan dalam bentuk perjanjian utang-piutang.

\footnotetext{
${ }^{15}$ Abdul Rasyid Saliman, op.cit, h. 90.
} 
Pelaku usaha atau masyarakat yang mendirikan perusahaan melalui modal yang dipinjam kepada para kreditur sering mengalami permasalahan hukum jika tidak mampu membayar utang-utangnya kepada para kreditur. Apalagi perusahaan itu mengalami kerugian dan tidak mampu membayar utang-utangnya kepada kreditur. kerugian di dalam Kamus Besar Bahasa Indonesia memiliki arti menanggung atau menderita rugi terhadap suatu perseolan tertentu yang disebabkan oleh faktor-faktor tertentu.

Untuk menyelesaikan permasalahan hukum dalam hal perusahaan mengalami kerugian dan tidak dapat membayar utang-utangnya kepada kreditur, dapat ditempuh melalui upaya hukum litigasi melalui pengadilan dan upaya non litigasi penyelesaian yang dilakukan diluar pengadilan. Dalam hal ini agar permasalahan dapat dileselaikan dengan cepat dan mudah tanpa membawa permasalahan hukum ke pengadilan dapat dilakukan upaya non litigas melalui novasi atau perjanjian pembaruan utang.

Novasi atau perjanjian pembaruan utang tidak memiliki aturan yang menjelaskan atau mengatur mengenai pengertian atau definisi mengenai novasi, namun di dalam peraturan hukum perdata atau KUHPer yang mana konsep novasi diatur dalam Pasal 1413-1424 yang pada intinya novasi atau perjanjian pembaruan utang merupakan suatu persetujuan pembaruan utang yang dilakukan oleh debitur dengan kreditur yang dibuat dalam bentuk akta. Pembaruan utang ini dilakukan setelah adanya perjanjian atau persetujuan utang-piutang, novasi atau pembaruan utang ini dilakukan jika debitur tidak mampu membayar utang-utangnya kepada kreditur.

Untuk menyelesaikan permasalahan hukum yang mana perusahaan mengalami kerugian dan tidak dapat membayar utang-utangnya dengan menggunakan upaya hukum novasi, makan berdasarkan konsep novasi yang pertama harus dilakukan sebelum terjadi permasalahan hukum dalam perusahaan yang didirikan yang mana modalnya didapat dari kreditur, maka pada saat peminjaman modal tersebut dibuat suatu perjanjian utang-piutang antara debitur dengan kreditur yang dituangkan di dalam akta yang dibuat oleh notaris, yang mana di dalam akta tersebut dimuat suatu klasula mengenai "penyelesaian hukum mengenai perjanjian utang-piutang yang akan dilakukan akan diselesaikan antara pihak terlebih dahulu".

Kedua, setelah dibuatnya perjanjian utang-piutang antara debitur dengan kreditur yang dimuat di dalam akta notaris, dan setelah adanya perjanjian utang-piutang itu debitur tidak mampu membayar utang-utangnya terhadap kreditur maka berdasarkan perjanjian terdahulu dibuat yang memuat klausula "bahwa permasalahan hukum akan diselesaikan oleh kedua belah pihak terlebih dahulu antara debitur dengan kreditur", maka kreditur dengan debitur dapat membuat perjanjian baru mengenai pembaruan utang debitur. Yang perjanjian ini dapat dilakukan dengan menunjuk debitur yang baru maka debitur yang lama tidak ada kaitannya lagi dengan kreditur, namun debitur lama memiliki kaitan dengan debitur yang baru. Begitu pula sebaliknya kreditur juga dapat menunjuk kreditur yang baru untuk menggantikan kreditur yang lama, maka debitur tidak memiliki kaitan dengan kreditur yang lama, namun sebaliknya memiliki kaitan dengan kreditur yang baru. Hal ini sesuai dengan ketentuan peraturan hukum perdata atau KUHper Pasal 1413.

Ketiga, karena novasi atau perjanjian pembaruan merupakan suatu jenis perjanjian maka berlaku konsep yang diatur di dalam Pasal 1320 yang memuat mengenai syarat-syarat sahnya perjanjian. Novasi atau perjanjian pembaruan utang baru diakui legalitasnya jika memenuhi syarat-syarat yang diatur di dalam pasal ini yang terdiri dari: 
1. Ada suatu kesepakatan;

2. Cakap menurut hukum;

3. Kesepakatan mengenai hal tertentu;

4. Hal yang disepakati tidak melanggar hukum.

Selain hal-hal penting yang dijelaskan diatas, ada beberapa yang perlu dicata bahwa novasi atau perjanjian pembaruan utang upayan yang dilakukan untuk mengantisipasi persoalan hukum atau perkara hukum yang akan terjadi dikemudian hari, maka sebelum terjadinya permasalahan hukum tersebut terjadi, debitur atau kreditur harus membuat perjanjian utang-piutang terlebih dahulu untuk dapat melakukan perjanjian pembaruan utang atau novasi. Karena itulah upaya hukum ini juga disebut dengan upaya hukum non litigasi, yang permasalahan hukumnya diselesaikan oleh kedua belah pihak dan tidak melalui pengadilan.

\subsection{Perbedaan Penggunaan Novasi Dan Penundaan Kewajiban Pembayaran Utang (PKPU) Pada Perusahaan Yang Mengalami Kerugian}

Masyarakat di Indonesia dalam menyelesaikan permasalahan hukum yang mana perusahaan mengalami kerugian dan dibitur tidak dapat membayar utang-utangnya lebih sering dilakukan dengan melalui jalur litigasi atau penyelesaian permasalahan hukum yang diselesaikan melalui pengadilan, karena memang penyelesaian permasalahan melalui jalur pengadilan dianggap lumrah oleh masyarakat karena pengadilan merpakan tempat orang untuk menyelesaikan permasalahan hukum. Walaupun memang ada upaya hukum yang bisa dilakukan di luar jalur non litigasi untuk menyelesaikan permasalahan hukum mengenai perusahaan yang mengalami kerugian sehingga debitur tidak mampu membyar utang-utangnya kepada kreditur bisa dielesaikan melalui upaya hukum novasi atau perjanjian pembaruan utang.

Penyelesaian permasalahan hukum melalui jalur litigasi dapat dilakukan dengan mengajukan permohonan kepailitan ke pengadilan oleh debitur atau oleh para kreditur, yang mana nanti hakim akan menilai apakah benar debitur yang perusahaanya mengalami kerugian ini tidak bisa membayar utang-utangnya kepada para krediturkrediturnya. Jika terbukti debitur tidak mampu membayar utang-utangnya maka pengadilan akan menyatakan bahwa perusahaan yang dimiliki oleh debitur yang tidak mampu membayar utang-utangnya ini telah mengalami kepailitan.

Setelah dinyatakan pailit oleh pengadilan debitur atau kreditur dabat mengajukan penundaan kewajiban pembayaran utang (PKPU) ke pengadilan untuk menyelesaikan persamasalahan utang-piutang secara damai dan untuk mendapatkan perpanjangan waktu bagi debitur agar bisa melunasi utang-utangnya baik setengah maupun sebagian. Penyelesaian hukum secara damai melalui PKPU yang mana perusahaan mengalami kerugian inilah yang lebih dikenal dalam masyarakat yang masih awam dengan perkembangan hukum di Indonesia.

PKPU ini tidak diberikan definisi atau pengertian di dalam peraturan perundang-undangan di Indonesia, namun konsep PKPU diatur di dalam Pasal 222 Undang-Undang Nomor 37 Tahun 2004 Tentang Kepailitan dan Penundaan Kewajiban Pembayaran Utang yang pada intinya menuntukan bahwa PKPU merupakan "permohonan yang diajukan oleh debitur atau kreditur yang mana debitur memiliki lebih dari satu kreditur, permohonan diajukan karena debitur diperkirakan atau tidak dapat melunasi semua atau sebagian utang-utangnya kepada kreditur-krediturnya pada waktu yang telah ditentukan, tujuan permohonan ini diajukan ialah untuk melakukan 
upaya perdamaian antara debitur dengan kreditur dengan tawaran membayar seluruh atau sebagian utang debitur.

Berdasarkan konsep PKPU dalam Pasal 222, maka PKPU memiliki beberapa unsur yang harus dipenuhi ialah sebagai berikut:

a. Pengajuan permohonan oleh debitur atau kreditur yang mana debitur memiliki lebih sari satu kreditur;

b. Debitur diperkirakan atau tidak dapat membayar utang kepada krediturnya;

c. Memiliki tujuan untuk mencapai perdamaian dengan tawaran membayar seluruhnya atau sebagian utang.

Penyelesaian permasalahan hukum yang mana perusahaan mengalami kerugian sehingga debitur tidak sanggup membayar utang-utanya jika dilakukan melalui upaya hukum PKPU, maka berdasarkan konsep PKPU yang terlah dijelaskan sebelumnya, yang pertama yang harus dilakukan ialah mengajukan permohonan pailit ke kejaksaan baik itu oleh debitur sendiri atau oleh para krediturnya sesuai dengan ketentuan Pasal 2 UU No. 37 Tahun 2004. Permohonan pailit ini dilakukan untuk dapat menyatakan bahwa memang benar perusahaan yang dimiliki oleh debitur benar-benar sesuai fakta mengalami kerugian dan tidak mampu membayar utang-utangnya.

Kedua, setelah dinyatakan pailit oleh pengadilan maka hal yang selanjutnya dilakukan yaitu, mengajukan PKPU baik itu dijukan oleh debitur maupun oleh kreditur yang mana debitur harus memiliki lebih dari satu kreditur, dan debitur benar-benar tidak dapat membayar seluruh utangnya atau sebagian utangnya. Setelah permohonan diajukan maka selanjutnya akan dilakukan proses di pengadilan.

Ketiga, jika permohonan PKPU dikabulkan oleh pengadilan maka selanjutnya berdasarkan Pasal 225, hakim atau pengadilan akan menunjuk hakim pengawas yang mana pengurus ini akan melakukan hal-hal pengurusan terhadap harta kekayaan debitur yang mana pengurus akan melakukan pengelolaan harta debitur, yang mana harta ini akan digunakan untuk membayar utang-utang yang dimiliki debitur. Pengurus ini memiliki peran yang sangat penting karena penguruslah yang akan melakukan pengurusan harta kekayaan dan pemberesan utang-utang debitur yang juga diawasi oleh hakim pengawas yang ditunjuk oleh pengadilan.

Sedangkan upaya hukum non litigasi yang dilakukan dengan novasi atau perjanjian pembaruan utang yang dilakukan untuk menyelesaikan permasalahan hukum yang mana perusahaan mengalami kerugian sehingga debitur tidak mampu membayar utang-utangnya yang berdasarkan konsep novasi di dalam Pasal 1413-1424 peraturan hukum perdata atau KUHPer yang mana novasi merupakan "suatu persetujuan pembaruan utang yang dilakukan oleh debitur dengan kreditur yang dibuat dalam bentuk akta. Pembaruan utang ini dilakukan setelah adanya perjanjian atau persetujuan utang-piutang, novasi atau pembaruan utang ini dilakukan jika debitur tidak mampu membayar utang-utangnya kepada kreditur".

Penyelesain permasalah dengan konsep novasi dilakukan yaitu, harus ada perjanjian utang-piutang terlebih dahulu antara debitur dengan kreditur-krediturnya sebelum adanya suatu permasalahan hukum, yang mana perjanjian ini dituangkan di dalam akta yang dibuat oleh notaris, yang mana di dalam akta yang dibuat akan memuat klausula yang mengatur mengenai "permasalahan jika debitur tidak mambu membayar utang-utangnya maka permasalahan yang demikian akan diselesaikan antara kedua belah pihak". Selanjutnya jika dikemudian hari terjadi suatu kerugian maka debitur dengan kreditur dapat melakukan upaya hukum novasi atau perjanjian pembaruan utang. 
Di dalam perjanjian pembaruan utang atau novasi yang akan dilakukan, debitur lama dapat diganti dengan debitur baru sehingga debitur lama tidak memiliki keterkaitan dengan kreditur, namun kretidur memiliki keterkaitan dengan debitur baru, begitu pula sebaliknya kreditur lama juga dapat diganti dengan kreditur baru sehingga kreditur yang lama tidak memiliki ikatan dengan debitur, namun debitur memiliki ikatan dengan kreditur yang baru. Hal ini sesuai dengan ketentuan yang diatur di dalam Pasal 1413.

\section{Kesimpulan}

Novasi atau perjanjian pembaruan utang yang dilakukan untuk menyelesaikan permasalahan hukum yang mana perusahaan mengalami kerugian sehingga debitur tidak mampu membayar utang-utangnya yang berdasarkan konsep novasi di dalam Pasal 1413-1424 peraturan hukum perdata atau kuhper yang mana novasi merupakan "suatu persetujuan pembaruan utang yang dilakukan oleh debitur dengan kreditur yang dibuat dalam bentuk akta. Pembaruan utang ini dilakukan setelah adanya perjanjian atau persetujuan utang-piutang, novasi atau pembaruan utang ini dilakukan jika debitur tidak mampu membayar utang-utangnya kepada kreditur”.

Penyelesain permasalah dengan konsep novasi dilakukan yaitu, harus ada perjanjian utang-piutang terlebih dahulu antara debitur dengan kreditur-krediturnya sebelum adanya suatu permasalahan hukum, yang mana perjanjian ini dituangkan di dalam akta yang dibuat oleh notaris, yang mana di dalam akta yang dibuat akan memuat klausula yang mengatur mengenai "permasalahan jika debitur tidak mambu membayar utang-utangnya maka permasalahan yang demikian akan diselesaikan antara kedua belah pihak". Selanjutnya jika dikemudian hari terjadi suatu kerugian maka debitur dengan kreditur dapat melakukan upaya hukum novasi atau perjanjian pembaruan utang.

\section{Daftar Pustaka}

\section{$\underline{\text { Buku-Buku }}$}

Peter Mahmud Marzuki, 2011, Penelitian Hukum, Kencana, Jakarta.

Abdul Rasyid Saliman, 2011, Hukum Bisnis Untuk Perusahaan: Teori Dan Contoh Kasus, Kencana, Jakarta, h. 91-92.

\section{Desertasi}

Manahan M. P. Sitompul, 2009, Penyelesaian Sengketa Utang Piutang Dengan Perdamaian Di Dalam Atau Di Luar Proses Kepailitan (Studi Mengenai Lembaga Penundaan Kewajiban Pembayaran Utang, Desertasi Program Pasca Sarjasa Universitas Sumatera Utara, Medan.

\section{$\underline{\text { Jurnal }}$}

Alfitri Satyaningrum, et.al , 2015, Problematikan Yuridis Pelaksanaan Novasi Subjektif Pasif Dalam Perjanjian Kredit Karena Pemberian Hak Tanggungan Meninggal Dunia, Jurnal Repertorium, ISSN:2355-2646. 
Anak Agung Adi Lestari, 2016, Perjanjian Baku Dalam Jual Beli Kredit Sepeda Motor Ditinjau Dari Undang-Undang Nomor 8 Tahun 1999, Jurnal Magister Hukum Udayana, Volume 5 No.2: 337-352.

Bagus Gede Ardiartha Prabawa, 2017, Analisis Yuridis Tentang Hak Ingkar Notaris Dalam Hal Pemeriksaan Menurut Undang-Undang Jabatan Notaris Dan Kode Etik Notaris, Acta Comitas, Volume 2 No. 1.

Kheriah, Independensi Pengurus Penundaan Kewajiban Pembayaran Utang (PKPU) Dalam Hukum Kepailitan, Jurnal Ilmu Hukum Riau, Volume 3 No.2.

Natalia Ningsih, at.al, 2017, Kekuatan Mengikat Akta Notarial Perjanjian Perkawinan Terkait Harta Bersama Yang Dibuat Pasca Pencatatan Perkawinan, Acta Comitas, Volume 2 No. 1.

I Gusti Agung Ayu Gita Priayanti Dinar, 2015, Penyelesaian Sengketa Pengalihan Saham Perusahaan Pembangkit Listrik Energy Panas Bumi Melalui Putusan Arbitrase Asing (SIAC), Jurnal Magister Hukum Udayana, Volume 4 No. 1: 4856.

I Gusti Bagas Arya Anggara Paramarta, 2017, Akibat Hukum Perjanjian Lisensi Terhadap Pihak Ketiga, Acta Comitas, Volume 2 No.1.

I Wayan Sukatra, 2017, Kedudukan Dan Hak Bank Terhadap Hak Preferen Upah Buruh Dalam Kepailitan, Jurnal Magister Hukum Udayana, Volume 6 No. 3: 300- 309.

\section{Undang-Undang}

Soedaryo Soimin, 2013, Kitab Undang-Undang Hukum Perdata, Sinar Grafika, Jakarta.

Undang-Undang Republik Indonesia Nomor 37 Tahun 2004 Tentang Kepailitan Dan Penundaan Kewajiban Pembayaran Utang, Lembaran Negara Republik Indonesia Tahun 2004 Nomor 131, Tambahan Lembaran Negara Republik Indonesia Nomor 4443.

Undang-Undang Republik Indonesia Nomor 3 Tahun 1982 Tentang Wajib Daftar Perusahaan, Lembaran Negara Republik Indonsia Tahun 1982 Nomor : 7, Tambahan Lembaran Negara Nomor : 3214 